\title{
Integration of Information and Communication Technology into Women Entrepreneurship in Uyo,
} Nigeria

\author{
Ernest S. Etim, Robertson K. Tengeh, Chux Gervase Iwu* \\ Cape Peninsula University of Technology, Cape Town, South Africa \\ ernieyoun@gmail.com, tengehr@cput.ac.za, iwuc@cput.ac.za
}

\begin{abstract}
Globally, entrepreneurship has steadily become the leading trend associated with growth regionally as well as nationally. It has lent itself to the significant and sustainable development of locally available resources and of human and social capital. More so, the establishment of microenterprises, together with small and medium scale businesses by women, is the most recognizable route to job creation, poverty alleviation, family well-being and women empowerment; apart from the social benefits accrued and direct impact to the community and environment. Unfortunately, despite the substantial resources invested by national and regional governments, international development organizations and other stakeholders for the enhancement of women entrepreneurship, several constraints still prevent women from attaining optimal performance in terms of business growth, annual turnover, and market capitalization. The use of information and communications technologies (ICT) has been suggested as another appropriate medium to assist with some of these challenges. A total number of 50 targeted female entrepreneurs in Uyo metropolis, Nigeria, were purposively sampled to take part in this study. Quantitative research design using semi-structured questionnaires was used to explore the influence of ICT on the entrepreneurial activities of female entrepreneurs. Descriptive and inferential statistics were adopted to interpret the primary data. Binary Logistics Regression resulted in Wald value $=1.353$ and $p=.245$, which is $>>.05$. The Wald chi-square test led to the rejection of the null hypothesis because of the $p$-value. Therefore, the leveraging of ICT tools did not have a significant effect on entrepreneurial activities among women entrepreneurs in the educational sector.
\end{abstract}

Keywords: Gender ICT use, Women entrepreneurship, Enterprise development, SMEs, Information Communication Technology

\section{Introduction}

The interplay of market forces and human entrepreneurial activities brings about enterprise formation. The enterprises that are created lead to economic development, employment opportunities, poverty alleviation, wealth generation and accumulation, social inclusion together with the economic well-being of the citizenry (UNCTAD, 2011). Gaps resulting from these dynamic activities lead entrepreneurs to innovatively invent products and/or services to exploit inherent opportunities in the marketplace. Unfortunately, in less developed economies (those of Latin America and the Caribbean, sub-Saharan Africa, North Africa and the Middle East, Eastern Europe and Central Asia), women entrepreneurship has underperformed despite available institutional support (Du Rietz \& Henrekson, 2000; Anna et al.,1999; Vossenberg, 2013). Statistically, women see no compelling motivation to be entrepreneurs (ADB, 2014), but when they eventually do, they aggregate to the informal sector, stay small in size, generating less income with fewer staff under their employment (ADB 2014; Carter \& Shaw, 2006; Sabarwal \& Terrell, 2008; Vossenberg, 2013).

Globally, women entrepreneurship is growing at a faster rate compared to their male counterparts (Global Entrepreneurship 2014 Women's Report cited by Pofeldt in Forbes, 2015). In advanced economies such as Canada, the aggregate contribution of female majority-owned SMEs in 2012 resulted in a CD $\$ 130$ billion net economic activity, or 7\% of GDP (Cooper, 2013) as reported in RBC Economics (2013), but then 86\% of female-owned SMEs are in certain sectors (professional services, accommodation and food services). A 2011 Survey on Financing SMEs (fewer than 500 employees and between $\operatorname{CD} \$ 30,000$ and $\operatorname{CD} \$ 500$ million in revenues) found that women were more likely to own smaller businesses (1-99 employees), than mediumsized ones (Toronto-Dominion, 2015). Undoubtedly, therefore, the improvement of entrepreneurial uptake among women can assist countries to increase their GDP, numbers of people underemployment, and the rapid bridging of the gender divide (ADB, 2014). Thus there is evidence that women-owned businesses contribute substantially to a nation's GDP. 
Rather disappointingly, women continue to be under-represented in business environments (looking at the self-employed or as owners of SMEs), have a lower turnover in terms of revenues and number of employees [typically 1-4] (Toronto-Dominion, 2015). According to RBC Economics (2013), this under-representation is as a result of (1) the inability to 'maintain sufficient cash flow'; (2) not recruiting and retaining skilled staff; (3) rising cost of inputs and instability of customer demand. Owing to these, developing economies, Nigeria included, will not derive the full benefits accruing from entrepreneurship (National Policy on MSMEs 2015). Even though these challenges are experienced by both men and women entrepreneurs, unfortunately, women entrepreneurs experience far greater challenges than men (Carter \& Shaw 2006; Ekpenyong, 2014; KSC, 2010; Matsoso \& Iwu, 2016; Mandipaka, 2014), in all aspects of enterprise operation. The "mobile revolution," brought about by information and communication technology (ICT) is responsible for the 'knowledge economy' which has transformed information into an asset to be traded and bought (Modinogale \& Kroeze, 2011).

The high growth in the US economy during the 1990s is reported to have been due to the early introduction of ICT (Lucchetti \& Sterlacchini, 2004), and proper leveraging of ICT is a driver of economic growth (Galloway \& Mochrie, 2005; Handzic, 2004). On the whole, information becomes an asset enabling small and medium scale businesses to become competitive (Mutula \& Van Brakel, 2006) in the new economy. However, SMEs in developing economies are disadvantaged owing to lack of proper ICT infrastructure, together with the necessary skills and expertise required to properly integrate ICT tools into daily business operations. Mutula and Van Brakel (2006) opine that "the ability of SMEs to survive in an increasingly competitive global environment is largely predicated upon their capacity to leverage information as a resource." In cognizance of this perspective therefore, it becomes imperative for SMEs to leverage ICT tools in the daily operation of their enterprises for maximum benefits. Essentially, the application of ICT in business has assisted in addressing issues of inequality, market access and positioning. Specifically, ICT usage has led to the 'reappraisal' of the traditional role accorded to women in the society (Afrah \& Tabiha, 2017; Maier \& Reichert, 2008).

Thus, utilizing ICT locally, women can prepare letters and memos, reports, store and retrieve data, analyze and plan their budget, make decisions, and solve problems (Ndubisi \& Kahraman, 2005); as well as access information on business development, better production technologies, compliances, market and pricing information, forecast and training (UNCTAD, 2014).Women entrepreneurs who rely on ICT thus become uniquely positioned to overcoming the many constraints [limited mobility, balancing work-life interphase, low skills and management expertise, lack of supportive business information, inadequate training, inability to access finance/credit, lack of previous experiences in business type] (ADB, 2014; UNCTAD, 2014), encountered in business operation. The additional self-confidence makes them counter gender bias and stereotyping due to cultural and traditional misconceptions the society places on women, giving them quick access to the supply chain, customers, financial and legal institutions, and management skills (Hisrich \& O’Brien, 1981; Motilewa. Onakoya \& Oke, 2015; UNCTAD, 2014).

The integration of ICT into women-owned businesses can however suffer due to lower purchasing power and several other factors. In fact, the Irish Small and Medium Enterprises Association (ISMEA) Report (2015), states that: "Entrepreneurship, science and technology, innovation and inventions are concepts mostly associated with men and male areas making these fields less attractive to women, resulting in women-related ventures, invention and innovation being less recognized as valuable business ideas." Apparently, this "digital divide" means that fewer women are integrated into the 'knowledge economy.' Therefore, in this regard, most female entrepreneurs cannot benefit fully from leveraging ICTs to business venturing due to this limitation. However, several reports (UNCTAD, 2010; UNCTAD, 2014; ADB, 2014) are of the consensus that leveraging ICT tools carry enormous benefits for women.

The Research Problem: ICT encompasses communication devices (television, radio, cellular phones, satellite systems, computer and network software and hardware), together with applications and services that come with them (Rouse 2005). Simply put, it implies any technology that can aid in information capturing, processing and transmission electronically (Ahmed, Ibrahim \& Oye, 2011). Dutta and Bilbao-Osorio (2012) opine that ICT involves technology used to handle information and communication. In reference to this study, ICT tools imply TVs, radios, cellular phones, and computers. The target population purposively chosen for this study necessitates the limitation imposed on ICT tools. On the whole, SMEs are being created in developing 
economies by both men and women. However, for female entrepreneurs issue arise with daily running of enterprises (Beverley \& Atsese, 2004), as well as persistent problems with adaptation of advanced technology into daily business operations (Beverley \& Atsese, 2004), leading to lower customer base, lower growth and profitability, diversification into other businesses hampered, questionable sustainability and longevity of the enterprises (Olasanmi, Ayoola \& Kareem-Ojo, 2012).

Relatively, only a small number of female entrepreneurs in developing countries do have exposure to ICTs (Tonetti, 2001), statistically implying a lower number of women using ICTs/or are digitally empowered. Some of these predicaments are highlighted below: "Women don't have as much access to the technology, so we have to make a special effort to increase women's access to ICTs" - Jens Karberg (ILO/UNCTAD 2014). "Information is power to a woman entrepreneur, and one of the best tools for a woman entrepreneur is providing internet services, secretarial services and telecenters ... We need special consideration for women's groups, to have specific telecenters which address the needs of women. ... And while women are aware of the challenges they face among themselves, we need men who are policymakers to hear the voices of women." Achamyelesh Ashenafi, President, Addis Ababa Women Entrepreneurs Association, Ethiopia and Managing Director, Konimix Trading (ILO/UNCTAD 2014). In Nigeria and particularly Akwalbom State, limited studies detailing the impact of ICTs on women entrepreneurship have been published. Generally, in advanced systems, studies show a positive impact on women entrepreneurial activities. Therefore, this study seeks to explore if the added advantages and benefits from using ICT tools reported in the literature, do have similar effects on female entrepreneurs in Uyo, Akwalbom State, Nigeria. Considering the above, we asked this pertinent question:

Research question: "Does the use of ICT tools (TVs, radios, mobile phones, and computers) have a positive benefit on business performance indicators," for female entrepreneurs in Uyo, Akwalbom State, Nigeria? The performance indicator this paper addresses is annual turnover owing to reports that utilization of ICT tools positively impacted finances of businesses in developing economies (UNCTAD, 2014; ADB, 2014). This basically means that ICT tools judiciously utilized in rural communities help female entrepreneurs overcome cultural, institutional and traditional stereotypes that impede entrepreneurial activities including the sourcing of funds.

Research objectives: In a study targeting female entrepreneurs in southern Malaysia, Alam, Jani and Omar (2011), were of the opinion that innovation through ICT usage had no impact or direct bearings on the success of female entrepreneurs in southern Malaysia. They suggested that the nexus between ICT and women's entrepreneurship could be applied to other cultures and nationalities. But in an opposing view Aleke, Ojiako and Wainwright (2011), studying the diffusion of e-commerce technology to small-scale Agribusiness in Nigeria, empirically found among local actors in Agribusinesses, the perception that ICTs influenced the development of business processes and the way existing processes could be further organized and enhanced. Also Moteliwa, Onakoya and Oke (2015) reported (in the Nigerian context), improved access to finance, ability to overcome cultural and educational challenges that impede business performance, freedom from time poverty, and ability of female entrepreneurs to operate "anywhere-anytime' business where time, space and distances were irrelevant due to ICT usage. The technical report by ILO/UNCTAD (2014) numerated possible indicators/measurements for the determination of a successful female entrepreneur to include: (a) ability of any female entrepreneur to overcome the challenge of the time imposed on her due to family responsibilities. Thus she should be able to balance her work-life responsibilities; (b) financial independence through acquired skills free of family pressures and impositions. Independent of family help, she earns enough for herself and family upkeep; (c) easy access to supply chain, customer base and value chain, together with availability of finance for business growth and expansion, (d) increased literacy rate and acquisition of educational skills due to appropriate social networking and business education, (e) global footprint from international contracts and recognition. Therefore, this study set out to achieve the following objectives: Evaluate the extent that women entrepreneurial activities are enhanced/or limited by the utilization of ICT, and What incentives are available to increase and/or improve on the numbers of women integrating ICTs into business venturing.

Research hypothesis: The following hypotheses were tested in this study: 
Ho $_{1}$ Work-life activities have been significantly improved by the utilization of ICT in business operations. Ho2 Entrepreneurial activities have been significantly improved by the utilization of ICT in daily enterprise venturing. The next section reviews literature in the following order: we chose our operational definition of SME from the one offered by the Small and Medium Enterprises Development Agency of Nigeria/National Bureau of Statistics (SMEDAN/NBS, 2013) as contained in the National Policy on MSMEs (2015-2025). Women entrepreneurship within the context of Nigeria and their overall features in the SME ecosystem is also examined. Thereafter, we reviewed the literature on ICT and its challenges to female entrepreneurs. This is followed by the section on methodology and analysis. The last section covers limitation of the study and future research areas, conclusion and recommendation.

\section{Literature Review}

SME definition: The term Small and Medium Enterprises (SMEs) is wide-ranging in definitions and can be described per country and type of economy (Ayyagari, Beck \& Demirguc-Kunt, 2007) one is dealing with. Ward (2018) opines that SMEs can also be characterized using a number of employees, annual sales, assets or a combination of the above. Generally, the number of employees, number of working hours, annual turnover, annual balance sheet or production volume, and company independence form the yardstick. However, the number of employees and annual turnover seems to be the criteria adopted by most countries and since it is economy/country dependent, cross country generalization is difficult (Harjula, 2008). For the purpose of this study, the characterization of an SME by the Small and Medium Enterprises Development Agency of Nigeria/National Bureau of Statistics (SMEDAN/NBS, 2013) as contained in the National Policy on MSMEs (2015-2025) suffices: SMEs refer to(1) a micro-enterprise that has less than 10 employees and assets [excluding land and building] less than N5million; (2) small-scale enterprise with less than 99 employees and assets from N5 million to N50 million, (3) medium scale enterprise with 100 to 199 employees and assets of N50 million to less than N500 million.

Women entrepreneurship: Globally, entrepreneurship has been regarded by regional and national governments as the best possible route to economic growth and the sustainable development of locally available resources. The motivation created by way of incentives and legislation by national governments acts as internal stimuli that drive innovation and creativity in the marketplace. This disequilibrium and resultant gaps, introduced into the business environment mean that entrepreneurs (male and female) are incentivized to exploit and maximize business opportunities for their benefits. Unwittingly and unknowingly, women that venture out due to opportunities created and out of necessity, soon discover that society puts a 'dent' on their creative potential. There are limits to their potential and fundamental human rights (Adebayo, 2015; Amuchi \& Asotibe, 2015; Ekpenyong, 2014; Mordi \& Okafor 2010). A number of studies have enumerated several constraints facing female entrepreneurs in developing countries (Adebayo, 2015; Carter \& Shaw 2006; Ekpenyong 2014; Matsoso \& Iwu 2016; Mandipaka, 2014; Richardson, Howarth \& Finnegan, 2004; Vossenberg, 2013).

Some of these challenges include: lack of access to finance, inadequate training and lack of information on business type, inability to maintain a proper life-work interface, women safety and gender biased violence, lack of societal support and role models, absence of social networks, outright discrimination due to gender bias and stereotyping, poor infrastructure, no proper legal and managerial advise, inability to access skilled and managerial personnel ( Adebayo, 2015; Carter and Shaw, 2006; Ekpenyong 2014; Matsoso \& Iwu 2016; KSC, 2010; Mandipaka, 2014; Nsengimana 2017; Richardson, Howarth \& Fennigan 2004; Vossenberg, 2013).These constraints-[institutional, systematic, customary, cultural practices, beliefs and norms] all impede women in their entrepreneurial activities (KSC 2010; UNCTAD 2014, ADB 2014). Therefore, most women resort to the informal sector where entry requirements are not stringent; running subsistence businesses (UNCTAD 2014; Vossenberg, 2013); consequently, statistics are not available to help national governments ascertain percentage contributions to GDP (UNCTAD 2014). The informal economy, affords then no legal rights nor social protection, status and recognition. In this age of information and data analytics, there is mounting evidence of a 'gender digital divide' (UNCTAD 2014), due to lower literacy rate, poor skills, no access to computers or the internet, resources, and other factors. 
They are missing out on the benefits provided by ICTs (UNCTAD 2014). Despite the inherent problems of ICTs integration and exposure by female entrepreneurs, repeated reports (ILO/UNCTAD 2014; ADB 2014); and studies (Afrah \& Fabiha 2017; Akomolafe \& Adegun, 2013; Olasanmi, Ayoola \& Kareem-0jo, 2012; Papastothopoulos \& Beneki, 2010) show accrued benefits to women entrepreneurship. Martinez and Williams (2010), opine that ICT use by entrepreneurs had innovatively brought about e-commerce, while Amit and Zott (2001) claim that utilizing ICT is a potent force in business venturing. ICT offered female entrepreneurs newer and improved opportunities for starting and growing their enterprises despite institutional, cultural, financial and educational constraints (Motilewa, Onakoya \& Oke, 2015).Broadly then, Motilewa, Onakoya and Oke (2015) are of the opinion, that balancing family responsibilities and business enterprising is achievable, together with societal norms and geographical distances confronting female entrepreneurs can be circumvented with the use of ICT tools [mobile phones, emails, video calls and conferencing] (Motilewa, Onakoya \& Oke, 2015). ICT offers to these women flexibility, time and resource management, independence and "anywhere-anytime" option of enterprise venturing. Cultural constraints prevalent in certain/most communities and a potent force in "destroying the entrepreneurial spirit," can be the 'initiator' of entrepreneurship (Motilewa, Onakoya \& Oke, 2015) for women are free to concentrate on businesses acceptable to their communities such as food and confectionaries, weaving and embroidery, pottery, fashion design, and beauty and health spars.

The feature of Nigeria's SMEs: The Nigerian landscape is dotted with micro, small and medium scale businesses which are operated by both genders (male and female). The rapid creation of micro and smallscale enterprises is due to the fact that start-up cost is low in comparison to larger firms; are reliant on local resources which generate employment for the community; has the tendency for adding value to the national GDP, together with stimulating rural and community development, thus acting as a deterrent for local migration to bigger cities. More so these firms spur entrepreneurial activity in rural communities, increasing the use of liquidity from local savings for productive purposes. Also they act as conduits for raw materials to larger firms, and income generation for local communities (Anamekwe, 2001; National Policy on MSMEs 2015). The operational structural problems of SMEs in Nigeria as outlined by Anamekwe (2001), and further reinforced by National Policy on MSMEs (2015) include:

- Management Problems - The tendency to have all important entrepreneurial and operational decisions made by one person (sole proprietorship), together with the notable absence of either training or updating of management and production skills. Additionally, there is usually no succession plan in place for the transition after the demise of the owner.

- Financing- This features highly on the pressing need of SMEs. The low business credibility, the absence of skilled management, inefficient and antiquated production facilities, limited collateral security, high-risk propensity, high failure and exiting rate, make it almost impossible to raise capital from appropriate and regulated channels. They then resort to other lenders at higher interest rates.

- Most operators and owners of SMEs tend to be imitators rather than innovators.

- The tendency to produce non-standardized goods/ or bridge copyright regulations during production.

- Marketing problems, arising from over-saturation and inadequate market analysis. Also offering products/services which may not be suitable to the particular market, due to lack of awareness of market opportunities/skills.

- A greater proportion of SMEs is concentrated in urban centres and could therefore not benefit from local opportunities e.g. cheap labor, access to primary (raw) materials. The probable reason for this is the poor infrastructure that entrepreneurs have to contend with in rural settings for it brings about added cost to enterprise operation.

- Little access to and or inability to apply new technologies e.g. computers or innovative production technologies. Thus, E-commerce is not considered as part of the business culture. This suggests that the owner makes all the decisions and is responsible for the accrued benefits. 
ICT definition: The definitions of ICT can always be contextualized (ICTs in education, healthcare. business or libraries), but can represent any of the following:

- ICT is an encompassing terminology that includes any communication device or application encompassing: radio, television, cellular phones, computer and network [hardware and software], satellite systems, as well as video-conferencing and distance learning (Rouse, 2005).

- The study, design, development, application, implementation, support or management of computerbased information systems. More so a synonym for computers and computer networks, but may be extended to telephones and television (Chandler, Daniel, Munday, Rod, 2011).

- ICT is the study, design, development, implementation, support or management of computer-based information systems, particularly software applications and computer hardware (United Nations Development Program, 2007). ICT then entails the capability to electronically input, process, store, and output, transmit and receive data and information including text, graphics, sound and video, together with the ability to control machines of all kinds electronically.

In summary then, ICT entails computerization and communications equipment and software necessary for the creation, design, storage, transmitting and manipulation of information in various formats. Hence personal computers, laptops, tablets, mobile phones, transport systems, televisions, and network technologies encompass the array of ICT tools (University of Queensland, Australia, 2012). The myriad definitions of ICTs and SMEs reinforce the "uniqueness of SMEs and the adoption of ICT tools." There is no need for generalization but each individual SME is different and ought to be treated as such (Taylor \& Murphy, 2004; Martin \& Matlay, 2001). Adopting this premise that SMEs in Nigeria have very little access to modern technologies in terms of ICT tools and the internet, it follows that SMEs in Nigeria are challenged in daily operation and service delivery to their respective clientele.

Benefits of ICTs to SMEs: Several numbers of studies (Afrah \& Tabiha, 2017; Ndubisi \& Kahraman, 2005; Motilewa, Onakoya \& Oke, 2015:101-102; Uluma, 2012; UNDP-APDIP, 2005) have alluded to the benefits that SMEs can have by adopting ICT. These may include (1) enhancement of the production processes because of efficient inventory management systems and lower production wastages; (2) improvements in accounting and budgeting practices, and the ease of information flow and better communication between the different units of the organization, which efficiently improve internal business operations; (3) the ease of connectivity to local and international contracts, leading to improved clientele base through the use of e-commerce. Thus, distances are bridged easily and cheaply, geographic barriers are removed and payments affected with point of sale platforms or e-payments; (4) the potential to outsource contracts to local and global supply chains and (5) a simplified approach to dealing with governmental regulations and taxation regimes. Additionally, according to Berranger and Windrum (2002), commercially, SMEs can benefit significantly due to their ability to extend their geographical reach, reacting swiftly to 'customer need;' procurement, production, and logistics can be effectively handled for cost reductions; huge potential for competitive advantage over global players through improvements in management skills and internal communication.

The internet reduces barriers experienced by new entrants and provides opportunities for small firms to reorientate their supply chain and then map out new strategic alliances in distant markets; ICT technology helps in the creation of newer and better business models, positioning smaller firms to adapt quickly to changing market environments and earn money from multiple sources. The UN (2002) maintains that ICT enables women to work from home; has the advantage to enable women transition from informal to formal economy; improved global outreach for craftswomen through e-commerce; transformation for gender roles in the community; women having the ability to avoid gender bias by adopting gender-opaque mediums; and increased access of rural women to distant learning and distant work programs. In summary then, ICTs can transform SMEs into information-driven enterprises, assisting them to adapt quickly to the knowledge economy. Businesses have presented the means through the integration of ICTs, a cheap and easy route of capturing and processing information often the domain of electronic transactions (Berranger \& Windrum, 2002).

Challenges to Female SMEs adopting ICTs: Lal (2007) in a report on the adoption of ICT by SMEs in Nigeria mentioned poor physical infrastructure as the major limiting factor hindering ICT usage and diffusion among SMEs. Peculiar to developing economies challenge to ICT are legal and regulatory issues, weak ICT strategies; 
inadequate research and development; excessive or over-dependence on foreign technologies and major weaknesses in ICT integration and implementation initiatives and policies. Adebayo, Balogun and Kareen (2013); Adenikinju (2005); Apulu and Emmanuel (2011); Lal (2007) Sajuyigbe and Alabi (2012) are of the consensus that lack of infrastructure, lack of funding, exorbitant cost of implementation, absence of awareness as to their benefits, absence of appropriate government policies, lack of skills and training, cultural factors, electricity challenges, corruption, illiteracy, low level of education, acted against the adaptation of ICT tools in business management practices in Nigeria. Maintaining these perspectives, female entrepreneurs are unable to fully exploit the benefits that can accrue from adopting ICT, because of advances made during the past decades and ever-growing ICT technologies available.

More so, since most women entrepreneurs are risk-averse and come from a low capital base, the high cost of ICTs and absence of business and technical skills, pose a serious problem to their integration into daily business operations. A Report from the UN (Division for the Advancement of Women/Department of Economic and Social Affairs 2002), details these problems in an attempt to empower women: a larger percentage of women entrepreneurs work in the informal sector, where institutional support is absent or negligible. The informal sector offers them neither protection nor accountability. In most developing economies, the absence of appropriate infrastructure for conducting e-commerce does not form part of the informal sector. Additionally, the absence of gendered access to neither ICT nor ICT training especially in rural communities not being part of government initiatives, language barriers experienced by women where English is not the mother tongue, and inappropriate information explaining the benefits of ICT integration (UN 2002). Some noted observations are the area where women's economic activities are most concentrated in developing countries is in the informal economy- women working at home on handicrafts and sewing or rolling cigarettes, working in cities as street vendors, - working without any contracts or benefits.

In some developing countries ninety percent of economically- active women are in the informal economy. How can ICT empower women in the informal economy? If ICT is to make a difference in alleviating poverty and improving the well-being of women and their families, it seems to me that this is the crucial area for concentration (Nancy Hafkin, USA 2002; in UN-Division for Advancement of Women). Linda Jones, Canada in (UN -Division for Advancement of Women 2002) the whole question of using ICT in the informal sector is a tough one -- there are issues of access, delivery of information, training, local language and content among others. In Pakistan, and other Islamic countries, the issues are exacerbated by the socio-cultural context. However, these are all issues that have been overcome in one way or another, and so represent challenges rather than absolute impediments. For instance, EmenOkon said, "I work in the Niger Delta region in Nigeria. Women's economic power has been greatly enhanced by the acquisition of ICT skills. This has enabled many women to gain employment into establishment such as the banks, corporate organizations, computer services, data entry and statistics, internet services providers and many others" (UN-Division for the Advancement of Women, 2002).

Women Light Organization, an NGO that works with female workers has turned out about 30 young women between January and now on computer skills and they are all gainfully self-employed Additionally, SMEs in developing economies do experience internal barriers due to organizational structures within the firm [sole proprietorship limits the leeway the business has for the owner makes all the decisions for the adoption of ICT tools into the business - owner/manager characteristics] (Kapurubandara \& Lawson 2006). These SMEs are exposed to other sets of impediments arising from infrastructure (technological, economic), legal, political, social and cultural unique to the country forming external barriers to ICT integration (Kapurubandara \& Lawson 2006). These two sets of problems must be addressed (organizational issues can be taken care off within the organization) but external barriers may need intervention from the government for these barriers to fall outside the domain of the firm. More so, firm's characteristics, inappropriate knowhow on use of ICT tools, together with cost and return on investment (Chau \& Turner, 2001; Knol \& Stroeken, 2001) prevent SMEs from the adoption of this technology.

\section{Research Methodology}

A positivist philosophical paradigm was adopted in this research to quantitatively justify the findings to either accept or reject the hypotheses developed during the study. A descriptive design helps quantify all the 
variables that were introduced during the study. The research instrument consisted of semi-structured questionnaires administered to the respondents. Female-owned private education and training organizations located in Uyo constituted the population. Primarily, to be chosen for this study, the female educational entrepreneur ought to have been in business for at least two years; must be involved in the daily running of the establishment; and must have used some form of information communication technology in the management of the business. These criteria limited the number of respondents and a total of 50 respondents, purposively sampled in Uyo metropolis, Akwalbom State were finally chosen. The research instrument comprised questions relating to characterization variables of age; educational qualifications, computer ownership, daily exposure to ICT tools (Olasanmi, Ayoola \& Kareem-Ojo, 2012). Ethical considerations were taken care of during questionnaire administration. For instance, full consent to participate was obtained from the subjects; they were not required to declare their identities, and they were also informed that they were at liberty to withdraw from the study as well as oblige with answers. The study area is Uyo metropolis in Akwalbom State. The state is in South Eastern part of Nigeria, Uyo being the state and financial capital. Statistically, Uyo has the largest concentration of SMEs in the State (Akwalbom State Statistical Year Book 2013), though representation of the total number of female entrepreneurs per business type was not available. This problem was circumvented by purposive sampling. More so, other restraining factors such as poor infrastructure, communication, and electricity to enterprise operation, are minimally reduced. The target population was 100 female entrepreneurs and a purposive sampling designed gave (70), with the eventual generation of primary data from only 50 respondents.

Variable measurement: Women entrepreneurs (entrepreneurial activities) is the dependent variable, examined based on educational level, union affiliation (optional), years in business enterprising, age-group and marital status. The use of ICT tools was the independent variable, determined/measured using mobile phones, computerization, radio and TV adverts (Olasanmi, Ayoola \& Kareem-0jo, 2012). These variables were measured with the help of the research instrument comprising semi-structured questionnaires (Olasanmi, Ayoola \& Kareem-Ojo, 2012). The questionnaires were administered after formal notification through telephone calls and short messaging service (SMS), ascertaining the appropriate time and date for questionnaire administration. The questionnaires were left with each respondent for completion and collected after one week.

Data analysis: Data was analyzed using IBM SPSS version 25; the descriptive statistics are given below:

\section{Results}

The demographics indicate ages ranging from 25 to above 64 years. Essentially, the greater number of female entrepreneurs in this sector, fall between 25 years and 64 years (88\%); equally reflected is their marital status which ranged from a single (40\%), married (42\%), divorced (4\%) and widowed (14\%). A greater number of female entrepreneurs were either single or married with educational qualifications of SSC/NECO (32\%), NCE (24\%), BA/BSc (22\%) and MA/MSc (14\%). Their years of working experience showed a variation ranging from two (2) to twenty-five, but a greater number of these women had 2years (25\%), 4years (34\%) and 6years (76\%) working experience. The family size lends credence to their business involvement/activities for the respondents -family sizes were from one (38\%), three (12\%), four (6\%), five (24\%), and six (18\%). These women were single and when married with children, they had to be able to deal with family responsibilities. Thus, for the effective running of any enterprise they had to be able to balance life/work responsibilities. Years of ownership of the enterprise varied from 2 years (22\%), 3 years (28\%) and 4 years (24\%); with a number of employees falling between 10 (54\%), $12(14 \%)$, and 15 (16\%). Legal status indicates that most female entrepreneurs operated a family business (42\%) acquired through transference and followed by joint ownership/partnership (30\%) either with associates/friends, partners or family members and sole proprietorship (28\%\%).The rationale for starting a venture varied from self-employment (14\%), improvement in financial position/financial independence $(12 \%)$, dissatisfaction with past employment (28\%), filling a gap in the marketplace (8\%), to family inheritance (38\%). These women therefore operated family-owned businesses in the majority of circumstances

Respondents' use of ICT tools: According to the respondents, $44 \%$ of businesses were networked while $56 \%$ were not. This showed that most of these women operated business ventures without access to 
information and therefore may not benefit from e-commerce. However, the reverse was true in their access to the internet (76\%) and only (24\%) said no. This might be explained on the basis that probably their mobile devices were connected.

Use of ICT tools in teaching/training of pupils/students: ICT tools form part of the media for training/teaching students and recruitment respectively. $64 \%$ of the respondent used ICT for teaching/training, while $36 \%$ did not. On the other hand, $88 \%$ of students/pupils were recruited by using ICT, and only $12 \%$ were not. In this regard, they had utilized other methods such as word of mouth, churches/mosques or social networks and acquaintances. 64\% of the respondents also advertised on social media. The demographics reported above are in line with previous studies but closely relates to Adeyemi's findings (2007) that the average Nigerian woman entrepreneur is: "aged 41, well-educated, married with children, grows up in an entrepreneurial environment, has previous work experience of about 8 years, runs a small business that has been operating for about nine years, and of which she is likely to be the sole or majority owner, prefers to have her family member as partner or employees, has her first attempt at starting a business, uses mostly her own savings as start-up capital; was motivated by personal factors when she decided to become an entrepreneur, faced start-up problems such as labor, financing and economic but today, faces increasing economic, labor and cost problems, rates her business as moderately successful" and attributes the success of her business to three qualities, that is quality of product/service, quality of human resources and her own personal qualities".

Respondents' use of ICT in business activities: Trying to rationalize the extent of business activities among female entrepreneurs in Uyo metropolis to understand performance (annual turnover), we observed that $44 \%$ agreed to ICT facilitating business venturing, while $26 \%$ disagreed with the notion; $30 \%$ were undecided. Equally, family responsibilities were easier to deal with (50\%), and 24\% were not in favor; $26 \%$ remained neutral. There is a split down the middle: women that were single (38\%) and newly married (12\%) giving a total of (50\%), may not be in a position where the number of children affected business venturing. There was overwhelming agreement from the respondents on the issue of annual turnover. $64 \%$ were in agreement that business activities had been affected in one way or the other by leveraging ICT tools, while $26 \%$ did not agree with the question. It would seem logical to note that those who had a negative view of the question may be having problems with the introduction of ICT technology or may not be in any position in the foreseeable future to be predisposed to the use of ICT technology. Similarly, the results show that $60 \%$ of the respondents' experienced marked improvements in a number of students recruited which then translated into an annual turnover. Unfortunately, 28\% were neutral while $12 \%$ saw no noticeable benefits.

Institutional support: For support from government and other institutions, $46 \%$ were of the consensus that governmental training was adequate and $28 \%$ did not. However, $26 \%$ were neutral. This result can be understood when the educational status and age group are factored into the equation for younger entrepreneurs are better educated and more access to general information. Additionally, $52 \%$ were of the consensus that government should invest more in infrastructure to facilitate business activities; $36 \%$ had the opposite opinion.

Table 1a: Classification Table ${ }^{a, b}$, and Variables in the equation

\begin{tabular}{|c|c|c|c|c|}
\hline \multirow[b]{2}{*}{ Observed } & & \multicolumn{3}{|c|}{$\begin{array}{l}\text { Predicted } \\
\text { Q23 Business enterprising has been } \\
\text { facilitated with the use of ICT tools }\end{array}$} \\
\hline & & Yes & No & Percentage Correct \\
\hline \multirow{2}{*}{$\begin{array}{l}\text { Q23 Business enterprising has been } \\
\text { facilitated with the use of ICT tools }\end{array}$} & Yes & 0 & 18 & .0 \\
\hline & No & 0 & 24 & 100.0 \\
\hline Overall Percentage & & & & 57.1 \\
\hline
\end{tabular}

Table 1a describes the baseline model (the University of Southampton cited in Restore, n. d.) which excludes the explanatory variable [here denoting the independent/predictor variable-measurable or operationalized and use to predict the outcome] (Restore, n. d.). This research showed that the prediction of the baseline 
model [here No], due solely from the fact that the participants did not achieve remarkable improvements in business performance -in terms of annual turnover (18 compared to 24 ). The overall percentage is $57.1 \%$, invariably the predictor is $57.1 \%$ of the time correct [chance occurrence] (Restore, n. d.).

Table 1b: Variables in the equation

Variables in the Equation

\begin{tabular}{llllllll}
\hline & & B & S.E. & Wald & Df & p-value & Exp(B) \\
\hline Step 0 & Constant & .288 & .312 & .851 & 1 & .356 & 1.333 \\
\hline
\end{tabular}

Accordingly, the variables in the equation are not too important but worth noting that $\mathrm{B}=0.288$, Wald chi square $=0.851 ; \mathrm{df}=1 ; p=.358$, and $\operatorname{Exp}(\mathrm{B})=1.333$.

Where $p=.356>>0.005$.

Using the $p$-value of .356 above, the study showed that the use of ICT tools significantly does not statistically affect business performance (annual turnover). Therefore, the model is simply a constant predictor of the expected outcome. On the other hand, if we use the results from the variables not in the equation, $p=.240$ which is by far greater than the significant $p$-value of 0.005 , there is no significant improvement to the predictor in the baseline model.

Variables not in the Equation

\begin{tabular}{llrll}
\hline & & Score & df & p-value \\
\hline Step 0 & Variables & $\begin{array}{l}\text { Use of ICT tools has made business1.383 } \\
\text { operations easier on me }\end{array}$ & 1 & .240 \\
& Overall Statistics & 1.383 & 1 & .240 \\
\hline
\end{tabular}

Table 1c: Omnibus Tests of Model Coefficients and Model Summary Omnibus Tests of Model Coefficients

\begin{tabular}{lllll}
\hline & & Chi-square & Df & p-value \\
\hline Step 1 & Step & 1.397 & 1 & .237 \\
& Block & 1.397 & 1 & .237 \\
& Model & 1.397 & 1 & .237 \\
\hline
\end{tabular}

\section{Model Summary}

\begin{tabular}{llll}
\hline Step & -2 Log likelihood & Cox \& Snell R Square & Nagelkerke R Square \\
\hline 1 & $55.968^{\mathrm{a}}$ & .033 & .044
\end{tabular}

a. Estimation terminated at iteration number 3 because parameter estimates changed by less than .001 .

A new regression model developed which included the exploratory (IV) variable resulted in the Omnibus Tests together with model summary above (Table 1c). The Chi-square values are all similar (1.397) and $p$ values of 0.237 [Cox \& Snell R Square= 3.3\% and Nagelkerke R Square= 4.4\%]. This result shows that there is no significant difference between the Log-likelihoods (-2LLs) of the original and the new model (Restore, n.d.). The model row in Omnibus test compares the new model to the baseline, while the step and block row become relevant when we step-wisely or in a hierarchical manner add the exploratory variables to the original model. Therefore, the omnibus tests show no significant difference between the new and original model and Nagelkerke's $\mathrm{R}^{2}$ of $4.4 \%$ give outcome variation (Restore, $n$. d.).

\section{Table 1d: Hosmer and Lemeshow Test}

Hosmer and Lemeshow Test

\begin{tabular}{llll}
\hline Step & Chi-square & Df & p-value \\
\hline 1 & 1.955 & 3 & .582 \\
\hline
\end{tabular}

Another result utilizing Hosmer and Leme show test showed a good fit for the model with $p=.582>>.005$. However, Chi-square is sample dependent and $p$-value may change when interaction is performed on our data (Restore, n. d.). 


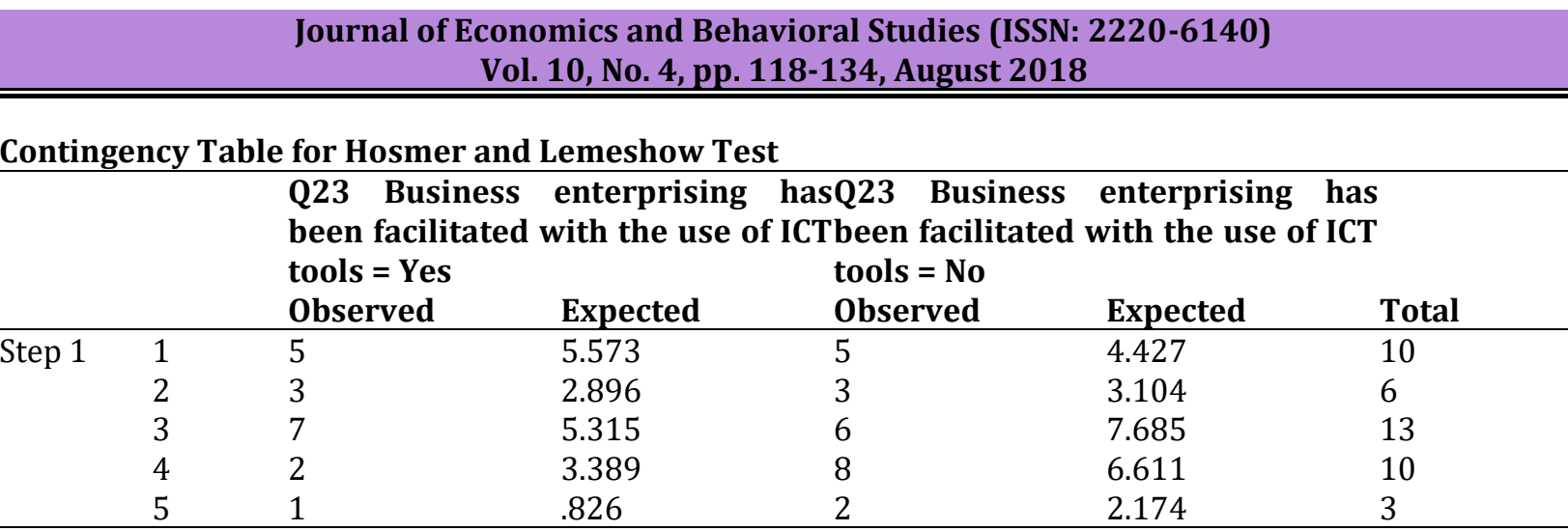

On the whole, logistic regression on the sample showed no marked significance statistically when ICT was integrated into business venturing.

\section{Table 2: Nonparametric Correlation}

\section{Correlations}

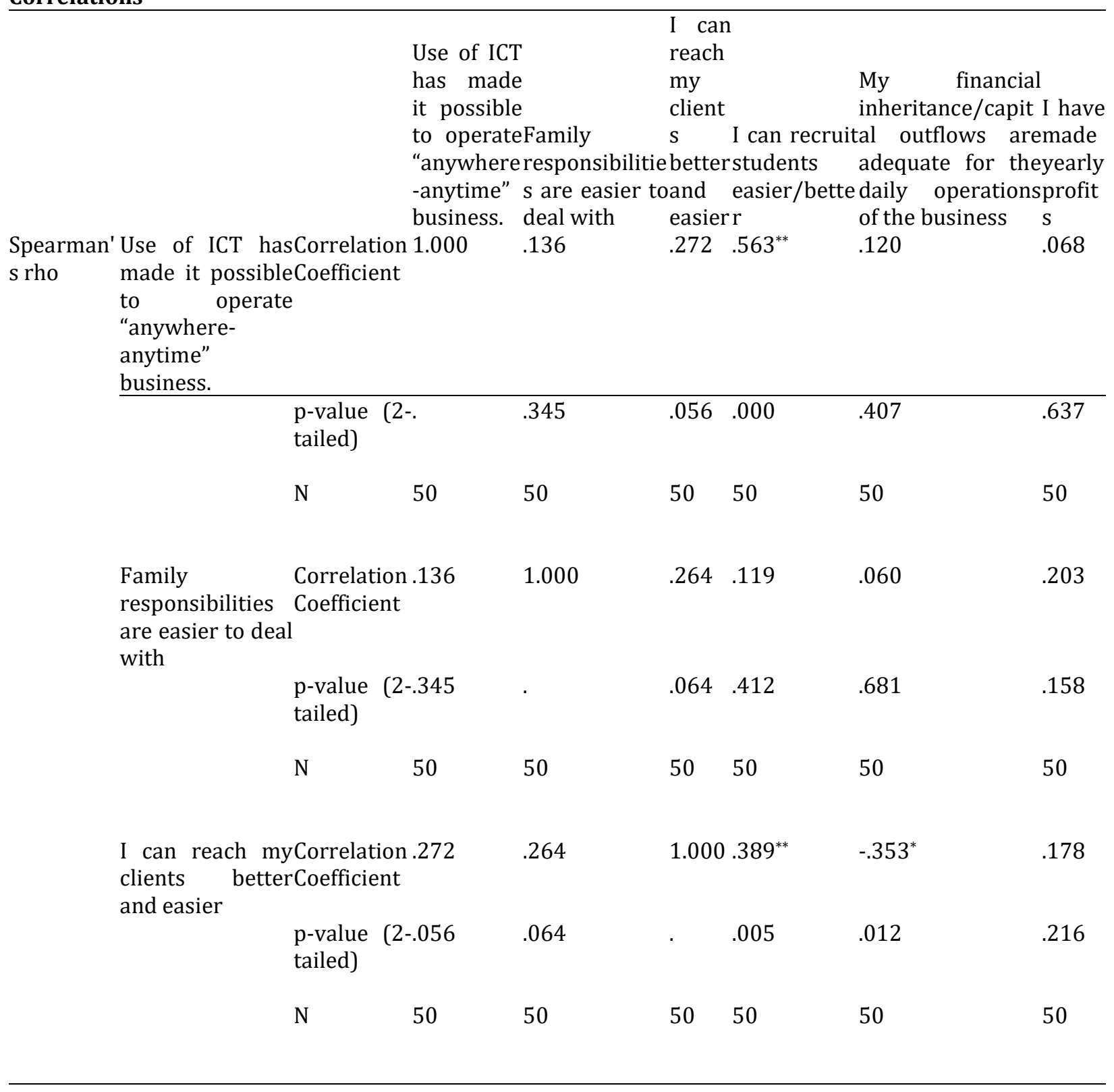




\begin{tabular}{|c|c|c|c|c|c|c|}
\hline \multicolumn{7}{|c|}{$\begin{array}{c}\text { Journal of Economics and Behavioral Studies (ISSN: 2220-6140) } \\
\text { Vol. 10, No. 4, pp. 118-134, August } 2018\end{array}$} \\
\hline \multirow{3}{*}{$\begin{array}{l}\text { I can recru } \\
\text { students } \\
\text { easier/better }\end{array}$} & tCorrelation $.563^{* *}$ & .119 & $.389^{\prime}$ & 1.000 & -.202 & $.298^{*}$ \\
\hline & $\begin{array}{l}\text { p-value }(2-.000 \\
\text { tailed) }\end{array}$ & .412 & .005 & . & .159 & .036 \\
\hline & 50 & 50 & 50 & 50 & 50 & 50 \\
\hline \multirow{3}{*}{$\begin{array}{l}\text { My financial } \\
\text { inheritance/cap } \\
\text { tal outflows are } \\
\text { adequate for } \\
\text { daily operation } \\
\text { of the business }\end{array}$} & Correlation .120 & .060 & -.353 & $*-.202$ & 1.000 & -.062 \\
\hline & $\begin{array}{l}\mathrm{p} \text {-value }(2-.407 \\
\text { tailed })\end{array}$ & .681 & .012 & .159 & . & .669 \\
\hline & 50 & 50 & 50 & 50 & 50 & 50 \\
\hline \multirow[t]{3}{*}{$\begin{array}{l}\text { I have made } \\
\text { yearly profits }\end{array}$} & $\begin{array}{l}\text { Correlation .068 } \\
\text { Coefficient }\end{array}$ & .203 & .178 & $.298^{*}$ & -.062 & 1.000 \\
\hline & $\begin{array}{l}\mathrm{p} \text {-value }(2-.637 \\
\text { tailed) }\end{array}$ & .158 & .216 & .036 & .669 & . \\
\hline & 50 & 50 & 50 & 50 & 50 & 50 \\
\hline **. Correlation is significant & $\begin{array}{l}\text { at the } 0.01 \text { level }(2 \\
\text { t the } 0.05 \text { level }(2-t\end{array}$ & $\begin{array}{l}\text { ed). } \\
\text { d). }\end{array}$ & & & & \\
\hline
\end{tabular}

\section{Variables in the Equation}

\begin{tabular}{lllllll}
\hline & \multicolumn{1}{c}{ B } & S.E. & Wald & df & p-value & Exp(B) \\
\hline Step 1 $1^{\text {a }}$ & $\begin{array}{l}\text { Use of ICT tools has made.299 } \\
\text { business operations easier } \\
\text { on me }\end{array}$ & .257 & 1.353 & 1 & .245 & 1.349 \\
$\begin{array}{l}\text { Constant } \\
\text { a. Variable(s) entered on step 1: Use of ICT tools has made business operations easier on me. }\end{array}$ & & & & & \\
\hline
\end{tabular}

The questionnaire developed to determine the correlation between the dependent variable (women entrepreneurial activities) in Akwalbom State in relation to the independent variable (leveraging of ICT tools to business venturing) was binary (Yes and No) in nature, hence it was rather not appropriate to use Pearson Correlation Coefficient, $r$, for this analysis. Rather we performed a nonparametric correlation test and observed two important correlation coefficients at $0.565^{* *}$, p-value 0.000 moderate correlation (between ability for recruiting of students and use of ICT tools), and a weak correlation $0.389 * *$; p-value (2-tailed) = 0.005.Due to this limitation, Binary Logistic Regression was used instead of simple linear regression for the study because of the imposition of dichotomy on the dependent variable (Statistics Solutions) Logistic regression normally becomes the acceptable statistical method employed to predict any relationship existing between predictors (independent variables) and a predicted variable (dependent variable which is binary in nature-here Yes/No).

Logistic Regression: Furthermore, the coefficient for the constant (intercept) in the model is .299; the standard error around the coefficient $=.257$; the Wald chi-square test for the null hypothesis is 1.353; the degrees of freedom is one (1), due to one predictor in the model, here the constant. The "Sig' or p=.245; while 
the exponentiation of the $\mathrm{B}$ coefficient (odds ratio) $=1.349$. The null hypothesis is rejected because $\mathrm{p}=.245$ which is much greater than .05. (Stats.stackexchange.com) the Wald test ['Wald column], for each independent variable determines the statistical significance (Statistics Laerd), found in the 'Sig.' column or $p$ value. Results show that the use of ICT tools for business venturing [Wald=1.353, $p=0.245$ ], did not add significantly to the model/prediction. In summary: a logistic regression was carried out to determine the effect of leveraging ICT tools on business venturing among female entrepreneurs in Akwalbom State, Nigeria; as a result of the introduction of a dichotomy into the question. The logistic regression model was not statistically significant; $\mathrm{p}=.245$ which is $>>.05$.

\section{Null Hypothesis}

$r=0 \quad$ null hypothesis, and

$\mathrm{r}<>0$ alternate hypothesis.

The correlation tests the null hypothesis that the population correlation is zero. In the study, the primary data was generated from 50 samples taken from a larger population. Normally sample outcomes may inherently be different from population outcomes, so finding a non-zero correlation in the sample does not prove that the 2 variables are correlated in the entire population.

Discussion: Results from descriptive statistics on data generated from female entrepreneurs in the educational sector showed a modest benefit from leveraging of ICT tools to business venturing. The rationale for these results can be interpreted from the notion that most of these entrepreneurs were not networked and had ICT tools improperly integrated and functional. The study group consisted of elements much younger in age (below 40 years); $48 \%$ family owned, and 30\% joint ownership. The respondents were limited in training, per the use of ICT tools, not sensitized enough to know the possible benefits that could accrue to them from the proper integration of ICT. $28 \%$ of the businesses were a sole proprietorship, which bestows the element of "uniqueness of SMEs and the adaptation of ICT technology" (Taylor \& Murphy, 2004; Martin \& Matlay, 2001); here the owner makes all the decisions. On the whole, Lal (2007) cites the major factors limiting ICT usage and diffusion among SMEs in Nigeria as legal and regulatory, weak ICT strategies, major weaknesses in ICT integration and implementation initiatives/policies, lack of funding, lack of adequate infrastructure, the exorbitant cost of implementation.

Additionally, Adebayo, Balogun and Kareen (2013); Adenikinju (2005); Apulu and Emmanuel (2011), opine that absence of awareness as to their potential benefits, absence of appropriate governmental policies, lack of skills and training, cultural factors, electricity challenges, low level of training, acted against the use of ICT tools in business policies in Nigeria. If these perspectives are generally accepted, then the results obtained above do not contradict these observations. It follows then, that a majority of female entrepreneurs are unable to proactively exploit the benefits of ICT technologies. These female entrepreneurs wanted more institutional support from the government by way of investments in infrastructure to enable businesses to thrive and grow remarkably in Akwalbom State. There should be a standing policy from the government to try to support women in business. The two hypotheses developed to test the significance of this relationship however, were not supported by the Spearman correlation coefficient values generated. Therefore, the alternate hypotheses hold. The limitation of this study was the imposition of certain criteria to be included in the survey group [sample] and concentration of the study on one sector of the economy.

\section{Conclusion and Recommendations}

This study set out to investigate how female educational entrepreneurs in Akwalbom State can meaningfully leverage ICT. ICT has been reported in the literature to assist business owners in strategizing and meeting the needs of targeted groups in the market place. Women entrepreneurship has specifically benefited from the leveraging of ICT tools (UNCTAD 2014; ADB 2014) to business venturing. The fact that there was no remarkable correlation between business performance (annual turnover) measured by the number of student intake at the various institutions, does not negate the importance of ICT to business operations. Women entrepreneurship has been part of the public domain for a while now. Governments, researchers, and other stakeholders are beginning to show interest in matters pertaining to female entrepreneurs in developing economies (Etim \& Iwu, 2018) ostensibly because of the realization that a vibrant economy calls 
for inputs from all segments of society. The contributory role of female entrepreneurs to the socio-economic development of their communities therefore calls for continuous attention. We recommend further studies targeting female entrepreneurs in other sectors of the economy before we can generalize any conclusion of ICT to the population. Also, the government and other stakeholders should listen to the plea of women and enact legislation or institute incentives that will spur greater entrepreneurial activities for women in Akwalbom State. Leveraging of ICT tools (Motilewa, Onakoya \& Oke, 2015; UNCTAD, 2014; ADB, 2014) have shown to catalyze women entrepreneurship. Future research could cover male-owned business (male entrepreneurs) in Akwalbom State. For instance, would ICT enhance or limit male-owned businesses in Akwalbom State? Studies on the quality of social networks (Aldrich, 1989) can determine business types and disparity between male-owned and female-owned businesses, as well as actual usage of social networks to improve on business performance (Oke, 2013) for female-owned enterprises. The adoption and use of social media for the enhancement of business processes could form a future line of research.

\section{References}

Adebayo, O. S., Balogun, O. J. \& Kareem, T. S. (2013). An investigative study of the factors affecting the adoption of information and communication technology in small and medium scale enterprises in Oyo State, Nigeria. International Journal of Business and Management Invention, 2(9), 13-18.

Adebayo, P. O. (2015). Impact of social-cultural values and individual attributes on women entrepreneurship. International Journal Management Science and Business Research, 4(12), 1-12.

Adenikinj, A. (2005). Analysis of the cost of infrastructure failures in a developing economy: the case of the electricity sector in Nigeria. Department of Economics and Centre for Economics and Allied Research, University of Ibadan, Nigeria. AERC Research Paper 148 African Economic Research Consortium, Nairobi.

Adeyemi, S. L. (2007). Nigerian women entrepreneurs and their personality traits. Center Point. Journal of Intellectual Scientific and Cultural Interests, University of Ilorin, Humanities Edition, 7, 179-188.

Afrah, S. H. \& Fabiha, S. T. (2017). Empowering women entrepreneurs through information and communication technology (ICT). A case study of Bangladesh. Management, 7 (1), 1-6.

Ahmed, M. S., Ibrahim, I. \& Oye, N. D. (2011). Role of information communication technology (ICT): Implications on unemployment and Nigerian GDP. Journal of International Academic Research, 11(1), $1-9$.

Akomolafe, C. O. \& Adegun, O. A. (2013). Promoting ICT opportunities for women empowerment in Nigeria: Issues and strategies. Retrieved from .http//www.oasis.col.org/bilstream/.../2013_Akomolafe\%26Adegun_PromotingICT.pdf.

Alam, S. S., Jani, M. F. M. \& Omar, N. A. (2011). An empirical study of success factors of women entrepreneurs in Southern Region in Malaysia. International Journal of Economics and Finance, 3 (2), 1-10.

Aldrich, H. (1989). Networking among women entrepreneurs. Hagan, Rivchun, C., \& Sexton, D. Eds, Praeger, New York.

Aleke, B., Ojiako, U., \& Wainwright, D. W. (2011). ICT adoption in developing countries: Perspectives from small-scale Agribusinesses. Journal of Enterprise Information Management, 24(1), 68-84.

Amit, R. \& Zott, C. (2001). Value creation in e-business. Strategic Management Journal, 22, 493-520.

Amuichie, A. A. \& Asotibe, N. P. (2015). Stimulating women potentials through entrepreneurship for national development in Nigeria. Journal of Poverty, Investment and Development, 8, 89-93.

Anamekwe, C. (2001). Micro and small-scale industries in Nigeria: Problems and prospects. Paper; presented at workshop on Grassroots Advocacy and Economic Development. September 11-13.

Anna, A. L., Chandler, G. N, Jensen, E., \& Mero, N. P. (1999). Women business owners in traditional and nontraditional industries. Journal of Business Venturing, 15(3), 270-303.

Apulu, I. \& Emmanuel, O. I. (2011). Are Nigerian SMEs effectively utilizing ICT? International Journal of Business and Management, 6 (6), 208 - 210.

Asian Development Bank [ADB]. (2014). Information and communication technologies for women entrepreneurs. Prospects and potential in Azerbaijan, Kazakhstan, the Kyrgyz Republic, and Uzbekistan. Retrieved fromhttp://www.adb.org.

Ayyagari, M., Beck, T. \& Demirgue-Kunt, A. (2007). Small and medium enterprises across the globe. Small Business Economics, 29, 415-434. 
Berranger, P. D. \& Windrum, P. (2002). Factors affecting the adoption of intranets and extranets by SMEs a UK study. (1st. Ed.) Manchester Metropolitan University, Manchester, ISBN: 1478-8209.

Beverly, M. K. \& Atsese, W. (2004). Female entrepreneurs in transitional economies: A comparative study of businesswomen in Nigeria and China, in Proceedings of Hawaii International Conference on Business, 21-24 June, Honolulu, Hawaii, (pp. 4-26).

Carter, S. L. \& Shaw, E. (2006). Women business ownership: recent research and policy development [Report] Retrieved from http://strathprints.strath.ac.uk/8962.

Chandler, D. \& Munday, R. (2011). A dictionary of media and communication (1 ${ }^{\text {st }}$ Ed.). Oxford University Press. ISBN-13 9750199568758. Online Version (2016) eISBN: 9780191727979.

Chau, S. B. \& Turner P. (2001). A Framework for analyzing factors influencing small to medium-sized enterprises (SMEs) ability to derive benefit from the conduct of web-based' electronic commerce (EC)- 34 Australian case studies, (pp. 623-639). ECIS 2002, June 6-8 Gdansk, Poland.

Cooper, L. (2013). Canadian women grabbing the baton.' Royal Bank of Canada Research. Retrieved from http://www.rbc.com/newsroom/_assets-custom/pdf/women-and-sme-10-2013.pdf.

Du Rietz, A. \& Henrekson, M. (2000). Testing the female underperformance hypothesis. Small Business Economics, 14(1), 1-10.

Dutta, S., \& Bibao-Osorio, B. (2012). The global information technology Report 2012: Living in a hyperconnected world. World Economic Forum. Retrieved from http://www3.weforum.org/docs/Global_IT_Report_2012.pdf.

Ekpenyong, S. N. (2014). Women entrepreneurship in micro, small and medium scale enterprises in Akwalbom State. Journal of Business and Management, 16 (3), 08-13.

Etim, E. S. \& Iwu, C. G. (2018). A descriptive review of the continued marginalization of female entrepreneurs in sub-Saharan Africa. (in press).

Galloway, L. \& Mochrie, R. (2005). The use of ICT in rural firms: A policy-orientated review. Emerald Group Publishing Limited, 7(3), 33-46.

Global Entrepreneurship Monitor. (2012). Global Report (2012) Retrieved from http://www.gemconsortium.org/report.

Global Entrepreneurship Women's Report. (2014). Women's entrepreneurship and innovation surge globally cited by Pofeldt Elaine in Forbes, 2015. Retrieved from https:www.forbes.com/sites/elainepofeldt/2015/11/27/womens-entrepreneurship-andinnovation-surge-globally/\#6734d7e70e7a.

Goswami, A. \& Dutta, S. (2015). ICT in women entrepreneurial firms. A literature review. Journal of Business and Management, 17(2), 38-41.

Handzic, M. (2004). Knowledge management: Through the technology looking glass. World Scientific, Singapore, 2004.

Harjula, H. (2008). Scoping study on the inclusion of release and transfers from small and medium-sized enterprises (SMEs) in PRTRs, environment and directorate. OECD, Paris, France.

Hisrich, R. D. \& O’Brien, M. (1981). The woman entrepreneur from a business and sociological perspective. Proceedings of the Conference on Entrepreneurship, Babson College, Wellesley, MA. 1981

ILO/UNCTAD Report. (2014). Empowering women entrepreneurs through information and communications technologies A practical guide.

ISME Report. (2015). Irish Small and Medium Enterprises Association: Women entrepreneurs, women in technology, skills need and balanced regional development. ISME Presentation to Joint committee on Jobs, Enterprise and Innovation. Retrieved from: https://www.isme.ie/assets/15041-jocPresentation-Women-ent-etc-pdf.

Kapurubandara, M. \& Lawson, R. (2006). Barriers to adopting ICT and e-commerce with SMEs in developing countries: An exploratory study in Sri Lanka. Proceedings of the 2006 Collector.

Knol, W. H. C. \& Stroeken, J. H. M. (2001). The diffusion and adoption of information technology in small- and medium-sized enterprises through IT Scenarios. Journal Technology Analysis \& Strategic Management, 13(2), 227-246.

Lal, K. (2007). Globalization and adoption of ICTs in Nigerian SMEs, Science, Technology Society, 12(2), 217244.

Lucchetti, R. \& Sterlacchini, A. (2004). The adoption of ICT among SMEs. Evidence from an Italian survey. Small Business Economics, 23(2), 151-168. 
Maier, S. \& Reichert, U. N. (2008). Empowering women through ICT-based business initiatives: An overview of best practices in e-commerce/e-retailing projects. MIT Press, 4(2), 43-60.

Mandipaka, F. (2014). An investigation of the challenges faced by women entrepreneurs in developing countries: A case of King Williams' Town, South Africa. Mediterranean Journal of Social Sciences, 5(27), 1187-1193.

Martin, L. M. \& Matlay, H. (2001). '"Blanket" Approaches to promoting ICT in small firms: Some lessons from the DTI Ladder Adoption Model in the UK,' Internet Research: Electronic Networking Application and Policy, 11(5), 399-410.

Martinez, C. A. \& Williams, C. (2010). National institutions. Entrepreneurship and global ICT adoption: A cross-country test of competing theories. Journal of Electronic Commerce Research, 11(1), 73-91.

Matsoso, M. L. \& Iwu, C. G. (2016). Women and small-scale entrepreneurship: Perspective from the SADEC region. eBook, Sense Publications, 197-213.

Modinogale, L. \& Kroeze, J. H. (2011). The role of ICT within small and medium enterprises in Gauteng Communications of the IBIMA Vol. 2011 Article ID 369288, pp. 12 Retrieved from http://www.ibimapublishing.com/journals/CIBIMA/cibima.html.

Mordi, C. \& Okafor, C. (2010). Women Entrepreneurship Development in Nigeria: the effect of environmental factors. The Petroleum-Gas University of Ploiesti, (4), 43-52.

Mutula, S, \& Van Brakel, P. (2006). Readiness of SMEs in the ICT sector in Botswana with respect to information access. Emerald. Retrieved from https//www.emeraldinsight.com/.../published/ emeraldfulltextarticle/pdf/2630240310_ref.html

Motilewa, B. D., Onakoya, A. O. \& Oke, A. O. (2015). ICT and gender-specific challenges faced by female entrepreneurs in Nigeria. International Journal of Business and Social Sciences, 6(3), 97-105.

Ndubisi, N. O. \& Kahraman, C. (2005). Malaysian women entrepreneurs: understanding the ICT usage behaviors and drivers. Journal of Enterprise Information Management, 18(6), 721-739.

Nsegimana, S. (2017). Challenges to women entrepreneurship in Kigali, Rwanda. MTech Thesis. Cape Peninsula University of Technology, South Africa.

Oke, D. F. (2013). The effect of social network on women entrepreneurs in Nigeria: A case study of Ado-Ekiti Small Scale Enterprise. International Journal of Education and Research, 1(11), 1-14.

Olasanmi, O. O., Ayoola, T. \& Kareem-Ojo, M. J. (2012). Evaluation of ICT use among women entrepreneurs in the Nigerian Garment Industry. International Journal of Management \& Business Studies, 2(1), 7-12.

Papastathopoulos, A. \& Beneki C. (2010). Does entrepreneurial experience and strategy really matter for ICT performance? A Greek cross-border empirical study, The Electronic Journal Information Systems Evaluation, 13(2), 177-186.

Pofeldt, E. (2015). Women's entrepreneurship and innovation surge globally in Forbes. Available at; https://www.forbes.com/sites/elainepofeldt/2015/11/27/women-entrepreneurship-andinnovation-surge-globsslly/\#76bfda4c70e7.

Richardson, P., Howarth, R. \& Finnegan, G. (2004). SEED Working Paper No 47. The challenges of growing small businesses: Insights from women entrepreneurs in Africa, International Labor Office, Geneva.

Rouse, M. (2005). ICT definition. Retrieved from https://collegeassignments.wordpress.com.

RBC Economics. (2013). Canadian women grabbing the baton. Retrieved from https://www.rbc.com/economics/economicreports/pdf/otherreports/canadianwomengrabbingthe baton.pdf.

Restore, (n. d.). Using statistical regression methods in education research. Retrieved from www.restore.ac.uk/srme/www/fac/soc/wie/research-new/srme/modules/mod4/12/index.html

Sajuyigbe, A. S. \& Alabi, E. (2012). Impact of information and communication technology in selected small and medium enterprises in Osogbo metropolis, Nigeria. Journal of School of Communication and Information Technology, Federal Polytechnic, Offa, Osun State, 3(1).

Sebarwal, S. \& Terreli, K. (2008). Does gender matter for firm performance? Evidence from Eastern Europe and Central Asia, IZA Discussion Paper No 3758.

SMEDAN/NBS. (2013). Small and Medium Enterprises Development Agency of Nigeria and National Bureau of Statistics, in Nigeria's National Policy on MSMES 2015-2025.

Southern, A. \& Tilley, F. (2000). Small firms and information and communication technologies (ICTs): Toward a typology of ICTs usage, New Technology, Work and Employment, 15(2), 138-154.

Statistics Laerd. Available at: www statisticslaerd.com.

Statistics Solution. Available at www.statisticssolution.com/spss 
Taylor, M. \& Murphy, A. (2004). SMEs and e-business. Journal of Small Business and Enterprise Development, 11(3), 280-289.

The University of Queensland, Australia. (2012). Available at: http://www.uq.edu.au/ICT/what-is-ICT.

Tonetti, B. R. (2001). ICT for women entrepreneurship in Asia-Pacific. Expert Group Meeting on ICT policy from a gender perspective. December 18th -19th, Asian Pacific Centre for Transfer of Technology (APCTT).

Toronto-Dominion (TD) Bank, Canada. (2015). Canadian women leading the charge into entrepreneurship. TD Special $\quad$ Report, $2015 . \quad$ Retrieved from https://www.td.com/document/PDF/economics/special/WomenEntrepreneurs.pdf

Uluma, N. B. (2012). Extent of ICT utilization among women in Mumias Division, Kenya, International Journal of Social Science and Humanities, 1(1), 22-25.

UNCTAD, (2010). World Investment/Trade and Development Report, New York, and Geneva.

UNDP-APDIP, (2005). United Nations Development Program-Asia Pacific Development Information Program. Initiated jointly by UNDP's Asia-Pacific Development Information Program (APDIP) and Asia-Pacific Regional Human Development Reports Initiative (APRI), the Report makes a significant contribution to our understanding of the potential and challenges of using ICTs to achieve human development

United Nations Conference on Trade and Development (UNCTAD). (2011). Information Economy Report 2011: ICTs as an enabler for private sector development, 2011. Geneva. Available at http://unctad.org/en/ Publications Library/ier2011_en.pdf.

UNCTAD, 2014. Empowering women entrepreneurs through information and communications technologies. A practical guide. UNCTAD/DTL/STICT/2013/2/Rev.1. 2014 Retrieved at unctad.org/en/Publications Library/dtlstict2013d2_en.pdf.

UN-Division for the Advancement of Women [On line Discussion]. (2002). Information and communication technologies and their impact on and use as an instrument for the advancement and empowerment of women. Available at https//www.un.org/womenwatch/daw/egm/ict2002/report/weel1.html

USAID Knowledge Services Center [KSC]. (2010). Constraints to Female Entrepreneurship in Sub-Saharan Africa, June 17, 2010.

Vossenberg, S. (2013). Women Entrepreneurship Promotion in Developing Countries: What explains the gender gap in entrepreneurship and how to close it? Maastricht School of Management, PO Box 1203, 6201 BE Maastricht, Nederland.

Ward, S. (2018). What are SMEs? Available at: https://www.thebalance.com/sme-small-to-mediumenterprise-definition-2947962. 